\title{
TECTONICS IMPACT ON POLJES AND MINOR BASINS (CASE STUDIES OF DINARIC KARST)
}

\section{VPLIV TEKTONIKE NA KRAŠKA POLJA IN MANJŠE KOTLINE (VZORČNE ŠTUDIJE Z DINARSKEGA KRASA)}

\author{
IVAN GAMS $^{1}$
}

\footnotetext{
${ }^{1}$ Pohorskega bataljona 185, 1000 Ljubljana
} 


\begin{abstract}
UDC: $551.24: 551.435 .83(234.422 .1)$

Ivan Gams: Tectonics impact on poljes and minor basins (Case studies of Dinaric Karst)

The aim of this study is to show tectonic features in selected poljes and minor basins in the Dinaric Karst. Boreholes and gravimetric measurements show thick Neogene loose sediments and the rocky bottom below the sea level - real cryptodepressions. The sediments make parts of a large plain that subsided at the end of the low Pliocene. The recent seismic activity in this area proves the ongoing tectonic process. The deepest (more than $100 \mathrm{~m}$ ) and the smallest polje in the Slovenian Dinaric karst, Globodol is a dry polje in the piezometric level. Quaternary subsidence of the bottom is the only reasonable explanation of its genesis. On Planinsko polje there are signs ob suballuvial corrosion and the indicators of the Holocene tectonic subsidence. Four poljes in the Ravni kotari (Dalmatia) are shallow basins in the first stage of development. They prove the process of the bottom levelling below the shallow cover of alluvial sediments. An extremely deep small basin is about $450 \mathrm{~m}$ deep Red Lake (Hercegovina) and small basins at Črnomelj and Kočevje (Slovenia), 300 m and 100 m deep below the sea level.
\end{abstract}

Key words: karstology, karst geomorphology, neotectonics, polje, Dinaric Karst.

Izvleček

UDK: 551.24:551.435.83(234.422.1)

\title{
Ivan Gams : Vpliv tektonike na kraška polja in manjše kotline (vzorčne študije z Dinarskega krasa)
}

Namen te študije je pokazati tektonske poteze v izbranih kraških poljih in manjših kotanjah Dinarskega krasa. Vrtine in gravimetrične meritve so ugotovile debele neogene nesprijete sedimente in apneniško dno pod gladino morja - kriptodepresije. Sedimenti so deli obsežne akumulacijske ravnine, ugreznjeni v kraška polja v spodnjem pliocenu. Seizmična aktivnost v sedanjosti nakazuje še trajajočo tektonsko aktivnost. Najgloblje (čez $100 \mathrm{~m}$ ) in najmanjše kraško polje v slovenskem Dinarskem krasu, Globodol, je suho kraško polje v piezometrični vodni gladini. Pliokvartarno grezanje dna je edina možna razlaga za nastanek polja. Na Planinskem polju so znaki podtalne korozije in holocenskega tektonskega grezanja dna. Štiri kraška polja v Ravnih kotarih (Dalmacija) dokazujejo proces uravnavanja jezerskega dna pod plitvim pokrovom aluvialnih sedimentov. Izjemno globoke majhne kotanje so okoli 450 m globoko Rdeče jezero (Hercegovina) in kotanji pri Črnomlju in Kočevju (Slovenija), okoli $300 \mathrm{~m}$ oziroma $100 \mathrm{~m}$ pod gladino morja.

Ključne besede: krasoslovje, geomorfologija krasa, neotektonika, kraško polje, Dinarski kras. 


\section{TECTONIC POLJES WITH NEOGENE SEDIMENTS}

Poljes take a small part of the karst areas in the world and also in the Dinaric Karst. Cvijić (1893) proclaimed the Dinaric karst for the karst of poljes and dolines. The word polje as the karstological term was for the first time adopted in the report on Bosnia and Herzegovina (polje means field - Mojsisowics, 1880). The precise number of the poljes in Dinaric mountains and elsewhere is dependant from the notion on polje. This notion is not uniform in the world as well in the karst sciences of nations which inhabit the Dinaric Karst. In the years 1971-72 the Commission for karst terminology in the Union of the Yugoslav geographical institutions wishing at least the unification of the terms polje and doline organised the meetings of the karst morphologists at Ljubljana. The sessions did not succeed and the three printed karst terminologies as a result of meetings (Slovenian, Croatian and Serbian) defined the polje quite different (Gams, 1973; Gavrilović, 1974; Roglić, 1974). From the definition of polje is dependant also the number of poljes found in the Dinaric Karst. Ballif (1896) cited 52 poljes, in this number are incorporated also basins in sense of large field. Šerko (1947) listed 298 larger basins, between them 70 as uvalas, 24 transitional forms between uvala and polje, and 114 poljes. Gams (1978) listed in the table essential data for 42 " most distinguished poljes". In the opinion that for a polje is enough a large surface of connected fields pedologist Jelavić A. (1982) cited in Dinaric Karst many hundred of "poljes" divided in the river valleys, proper karst poljes and uvalas. Differ also genesis of the polje. Based mostly on the Yugoslav literature Sweeting M. (1972, 200) concluded, that poljes are always guided by tectonic lines in the area of faults or (and) folds associated with impermeable strata in the limestone basin and formed by differentiated erosion.

Poljes of Dinaric karst are dealt with in numerous scientific papers and monographs, there is therefore no more need to repeat their contents nor their classification according to the hydrology (s. Mijatović, 1884). morphology (Lehmann, 1959), situation of permeable and impermeable lithology, climate (tropical etc), chorology, genesis (Gams, 1973). Here are dealt selected basins of tectonic origin, poljes, collapse dolines and small filled basins in the Dinaric Karst. For us is polje a basin with at least 400 wide flat bottom in the karst area with underground outflow and with uninterrupted higher circumference

Tectonic poljes and cryptodepressions of Livno, Glamoč and Duvno are in the high Bosnian Dinaric Karst close to border with Dalmatia and Croatia (Sketch 1) at the watershed between the Cetina (Adriatic drainage area) and the Sava river (Danube, Pannonia).

Polje of Livno is the greatest polje in Dinaric Karst. The plain bottom $\left(300 \mathrm{~km}^{2}\right)$ in the altitude $700-710 \mathrm{~m}$ is $69 \mathrm{~km}$ long and $7-15 \mathrm{~km}$ wide. The south-eastern end of the polje is called Buško Blato where the marshy bottom was often inundated, now it is used for the water storage for the HE power station Cetina. Inundations occur also in the rest of the polje bottom, as it is completely deforested for meadows and pastures what increased the flooding elsewhere in the world . The villages are located on the small rubble fans formed mostly during Pleistocene cold climate below the grey rocky slopes built of Cretaceous limestone.

The polje bottom is built of the upper Miocene and lower Pliocene (Sarmatian) loose sediments, consisted mostly of clay, loam, sand, marl, and locally inlayers of lignite, long time used in the coalmine. Without its SE end -Buško Blato the difference in height between the rocky surroundings (up to $1450 \mathrm{~m}$ ) and polje bottom $(700-710 \mathrm{~m}$ ) is in average $750 \mathrm{~m}$.

$11 \mathrm{~km}$ distant from Livno polje is the polje of Glamoč $\left(129 \mathrm{~km}^{2}, 45 \mathrm{~km}\right.$ long in the same direction, NW$\mathrm{SE}$ ), its bottom at $882 \mathrm{~m}$ of altitude is built of the same Neogene loos sediments and tuff as inlayer. 
$30 \mathrm{~km}$ SE from SE border of Glamoč polje and $7 \mathrm{~km}$ from Buško Blato is the polje of Duvno (121 km² , $860-890 \mathrm{~m}$ altitude), with similar Neogene carbonatic sediments, its rocky bottom is 500 $\mathrm{m}$ below the same Neogene "lake" sediments and sandstones.

The mentioned poljes are the most impressive and the most cited poljes in the karst literature. The role of tectonic is mostly described with words "controlled by syncline or faults", and the recent morphological processes as "differentiated karst processes" Both words can be understood differently (Roglić, 1940, 1954).

The most detailed analysis of the western Bosnian poljes of Livno, Duvno and Glamoč has published Baučić (1967, 116 - 119). He used the results of the 137 reports of the civil engineers of the Institute for geological research of the republic Croatia at Zagreb, based on boreholes and gravimetric measurements. Research was done for the foreseen use of these poljes for water storage of the HE station on the river Cetina. For our aim are important the following data. In the upper Miocene (Styrian orogenic phase) about 1500 - 500 m thick sediments of sandstone, marl, clay, conglomerate and coal layers have been accumulated. On the base of uniform grain structure of this sediments in all poljes Baučić concluded, that they have been accumulated in one single larger paleodepression. After Miocene follows a break in the sedimentation as the higher strata are discordant. On the Miocene accumulation are low Pliocene sediments, in the poljes of Livno and Glamoč consisting of about $2000 \mathrm{~m}$ deep marl, clay, silt, loam, sand and inlayers of coal. Also Baučić speaks on lake sediments.

The depths of Neogene sediments (acc. to Baučić) is given in the lower table.

\begin{tabular}{|l|c|c|c|}
\hline \multicolumn{1}{|c|}{ Polje } & Livno & Glamoč & Duvno \\
\hline Altitude, $m$ & $700-710$ & $882-950$ & $860-890$ \\
\hline Thickness of Neogene sedim. $m$ & 2000 & 500 & 2000 \\
\hline Altitude of the rocky bottom, $m$ & $-1300-1310$ & $382-450$ & $-1140-1110$ \\
\hline
\end{tabular}

Without Neogene sediments the rocky polje basins of Livno and Duvno would be 1100 $-1310 \mathrm{~m}$ below sea level as cryptodepressions. The rocky basins are in this light the results of the contemporary sinking and of the rising the land surface around. There is at present time in the average above $1100 \mathrm{~m}$; W of the Livno polje the peaks rise in the Dinara mountain to 1912 m Troglav, and Vršak, 1576 m above Duvanjsko polje, 1113 m above Glamočko polje on W and $2005 \mathrm{~m}$ on its east side. Plateaus are mostly on the NW and SE side of the poljes. The polje bottoms are not a limestone plain; the gravimetrical measurements have shown differences up to $150 \mathrm{~m}$ in short distance. Thickness of the total Neogene cover on the surface hase been probably less then $1000 \mathrm{~m}$ as the sinking of the polje bottom provoked on surface the accelerated denudation of sediments into the growing basin.

The thesis of Baučić and some other researches of Dinaric poljes that their basins are older than Neogene sediment in them is doubtful. In all climates, even of the Mediterranean type, the mechanical weathering of the rocky slopes would provoke rubble slides and rock falls. They are not mentioned as an essential part of the Neogene sediments. They are accumulated locally on the Neogene sediments on the foot of slopes as fans, especialy in the Glamoč polje, and have been formed presumably in cold Quaternary climate mostly. If the Neogene sediments would be formed on the surface and later transported into the sinking basins by river, this fact could be evident in coarser sediments at 
the river mouth and in the diminishing grain sizes toward the opposite side. This differences are not found. Buško Blato as the southeastern part of the polje of Livno has different sediments, they are only about $500 \mathrm{~m}$ thick. The Miocene and Pliocene small grained "lake" sediments as clay, silt, loam, sand and marl in poljes of Livno and Glamoč prove by themselves their origin on the large lowland with thick sedimentary cover.

The nearest larger plain of alluvial tiny sediments are in the $150 \mathrm{~km}$ distant plain along the lower rivers Vrbas and Sava North of Banja Luka and in more distant Karlovac basin. Along the Sava river are between Sisak and Šabac locally $1-3 \mathrm{~km}$ deeper basins filled up with Neogene sediments, and locally also in plains along the right tributaries. The loose Neogene polje sediments in our poljes are in this view older than Dinaric Mountains raised by advancing Adria tectonical plate toward NE. Around the polje of Livno the mountains reach on the NW side up to $1912 \mathrm{~m}$ (peak Troglav) and on the opposite side1555 m (Radički vrh).

The relief between the Danubian and Adriatic basin after the upper Miocene has completely changed with rising of the Inner and Outer Dinarides as a consequence of the collision between the Dinarides and Adriatic lithosphere plate (Herak, 1972)

Tectonic origin of the west Bosnian poljes is here not published for the first time. Already Cvijic (1901), Katzer (1903) and Grund (1903) have nearly in the same time stated: the Neogene sediments of the poljes have been deposited in quite larger area and they are now conserved inside of poljes due to their tectonical sinking. This statement have been published by the then students of the university of Vienna and in the same geographical monographs (Roglić, 2004, 260) Their conclusion on the polje development in Western Bosnia was later overlooked. Why? Cvijić has later under the influence of W. Morris Davis theory on erosion (geographical cycle) temporary changed his opinion on genesis of poljes in favour of their genesis from a doline to uvala and it to a polje The second reason is probably the first world war with separation of the Balkan countries from Austrian-Hungary empire and disruption of scientific collaboration. Baučić (1967) recognized otherwise that the Miocene sediments in the poljes of Glamoč, and in the $15 \mathrm{~km}$ distant polje of Livno show equally

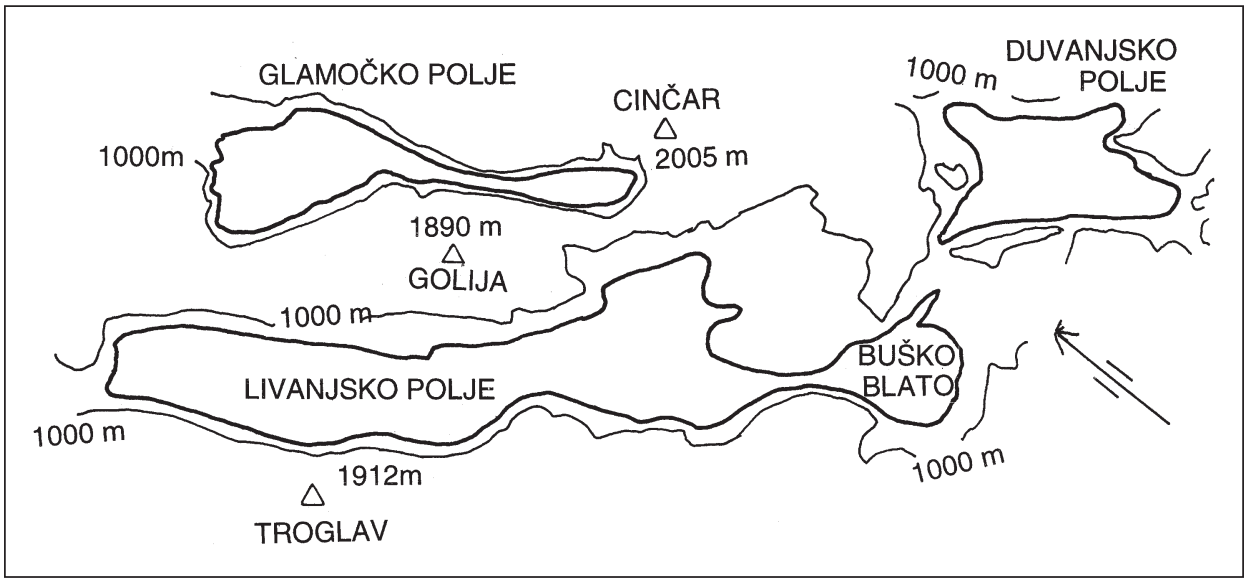

Fig. 1: Poljes of the western Dinaric Karst.

Sl. 1: Kraška polja v zahodnem Dinarskem krasu. 
sequences as they derived from one single larger common paleodepression on the surface. But he speaks in spite of this in general of the lake sediments. Special kinds of cave fauna in west Bosnian karst caves indicate the Tertiary connection of Panonian Sea (Lake) and Mediterranean Sea (Rep. of C. Deeleman).

The contemporary knowledge on effects of tectonics in the zone of asthenosphere on the relief in the alpine orography brought possibility to explain sinking and rising also of minor parts of land in size of some square kilometres as an effect of strike-slip faults on the karst depression. In this light is important to consider the described polje forms (see sketch !). The polje of Livno is in the middle narrower than at the NW and SE end at the town Glamoč. Buško blato is more rounded and formed probably by other pull-apart process. The SE end of the polje of Glamoč is $4 \mathrm{~km}$ wide and at the NW $7 \mathrm{~km}$. The middle part is at the narrowest place 1-2 km wide and there is up to $800 \mathrm{~m}$ high gorge with steep slope. We do not know the kinds of faults in the polje rocky bottom. Duvanjsko polje has a form of triangle with longer extension toward North.

The sinking of our poljes began in the lower Miocene and lasted presumably till the present time. The seismic station at Glamoč registered in the period 1946 - 1982 the strongest earthquake of $7^{\circ}$ scale of MCS ( equal to new Eu- scale). In the early year 2005 an earthquake of there has been registered also in the more than $210 \mathrm{~km}$ distant Slovenia.

The statement on contemporary sinking of the treated poljes together with their Neogene sediments is based on faster evacuation of Neogene sediments than in limestone after the beginning of a polje basin. The rocky slopes in Cretaceous limestone of the poljes of Livno and Glamoč are in average many hundred metres high. In rocky slopes are absent large caves as ancient ponors. The only large ponor in the polje level is near Kovač in the polje of Glamoč with water connection to Livanjsko polje (Roglić, 2004).The modest mechanical erosion in sediments is evident from the absence of valleys on the flat surface of sediments. A reduced water permeability in limestone around our poljes have proved numerous tracings of underground connections of poljes with the river Cetina. Their bottoms are at high water level more or less flooded.

The evacuation of upper Neogene sediment from poljes was in the old literature attributed to the erosion or diversified erosion or karst erosion not knowing that the Neogene sediments in our

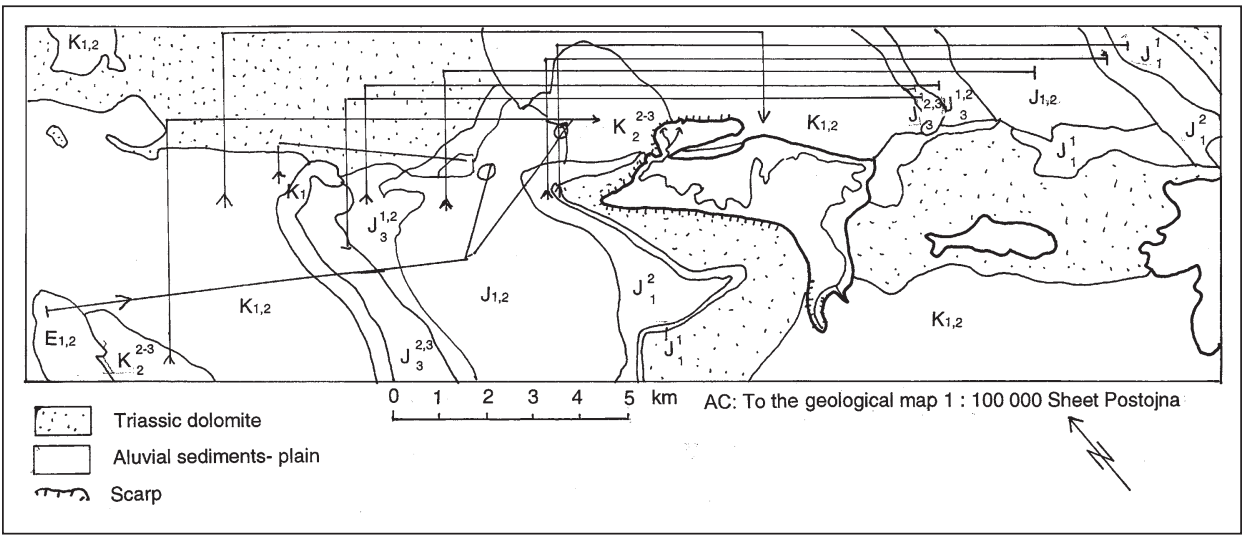

Fig. 2: Geological and tectonical sketch of Polje of Planina region.

Sl. 2: Geološka in tektonska skica Planinskega polja z okolico. 


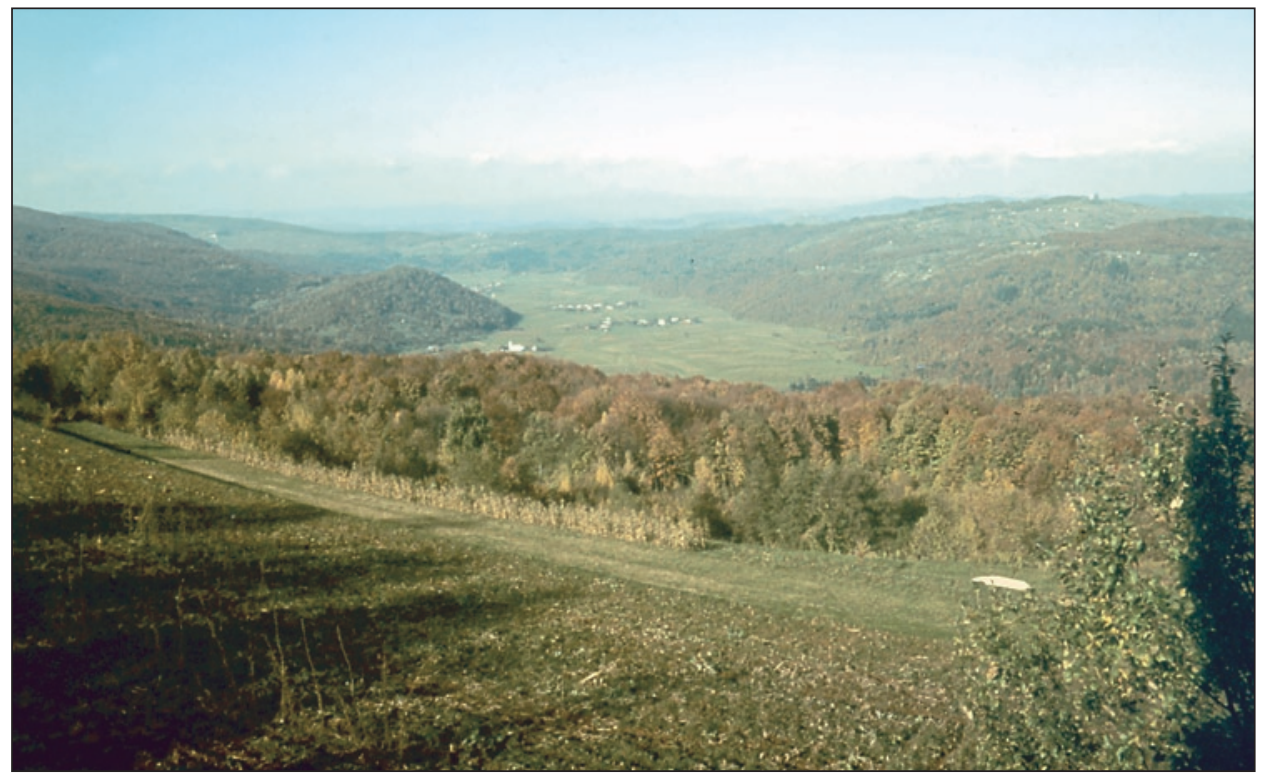

Photo 1: Polje Globodol, taken from South. In the polje is visible the hill Mali vrh, mentioned in the paper. (Photo I.Gams).

Foto 1: Globodol, slikan od juga. Na polju je viden hrib Mali vrh, ki je omenjen v tekstu. (Foto I.Gams).

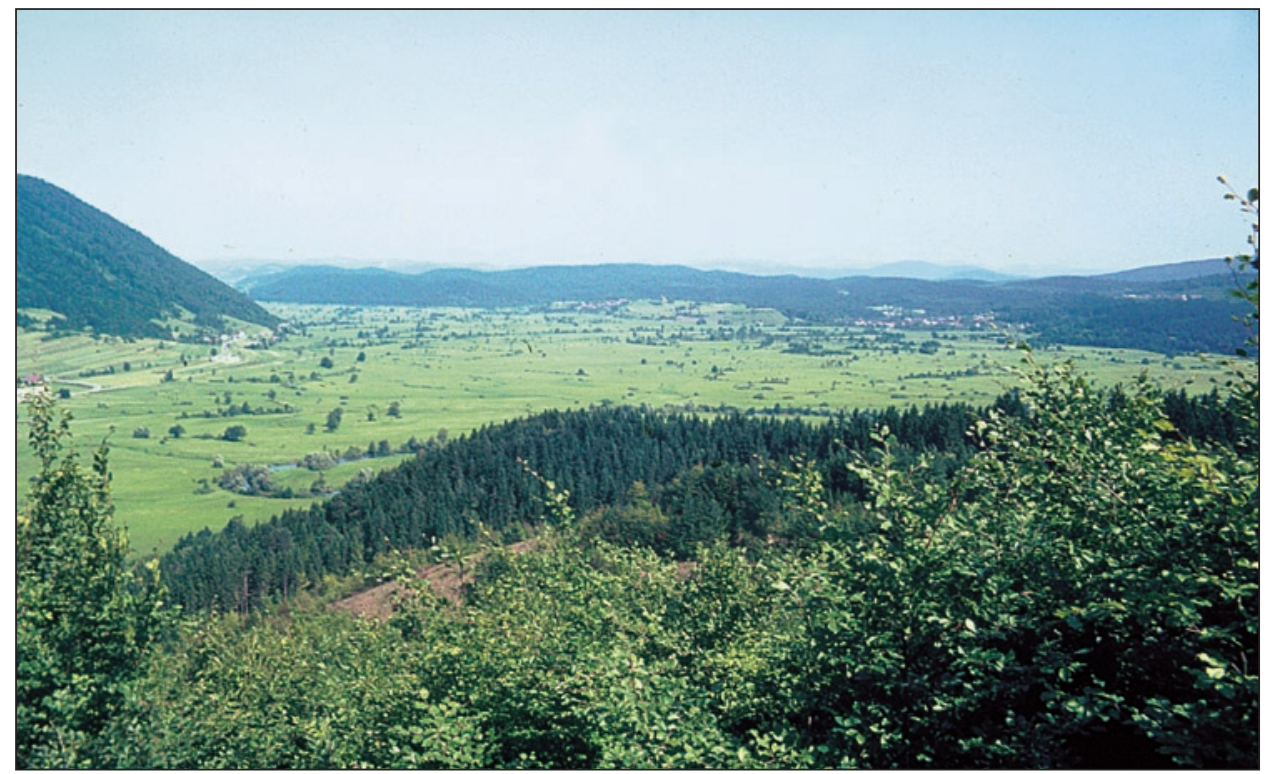

Photo 2: Polje of Planina taken from SE. (Photo I.Gams).

Foto 2: Planinsko polje, slikano od JV. (Foto I. Gams). 
poljes are a kind of molasa (at the foot of Alpine) and also in Pannonian part of Slovenia more or less carbonatic (Gams, 1981). So are also in Bosnian poljes.

The pedologist Jelavić $\left(1982,137\right.$ - 139) as the first has measured the content of $\mathrm{CaCO}_{3}$ and $\mathrm{MgCO}_{3}$ in the poljes. In soil and beneath downward the $\mathrm{pH}$ is increasing and in the depths of 130 - $230 \mathrm{~cm}$ he found in the polje of Livno up to $57,4 \%$ of $\mathrm{CaCO}_{2} \mathrm{MgCO}_{3}(\mathrm{pH} \mathrm{8,6)}$ in the polje of Glamoč in the depths of $250-270 \mathrm{~cm} 58,8 \%$, and in the depth of $250-270 \mathrm{~cm}$ in the polje of Duvno $84 \%$.

In the loose carbonatic sediments whenever they are in contact with rain water, the solution is faster than in the limestone. This has shown also the measurement of Neogene sediments in the

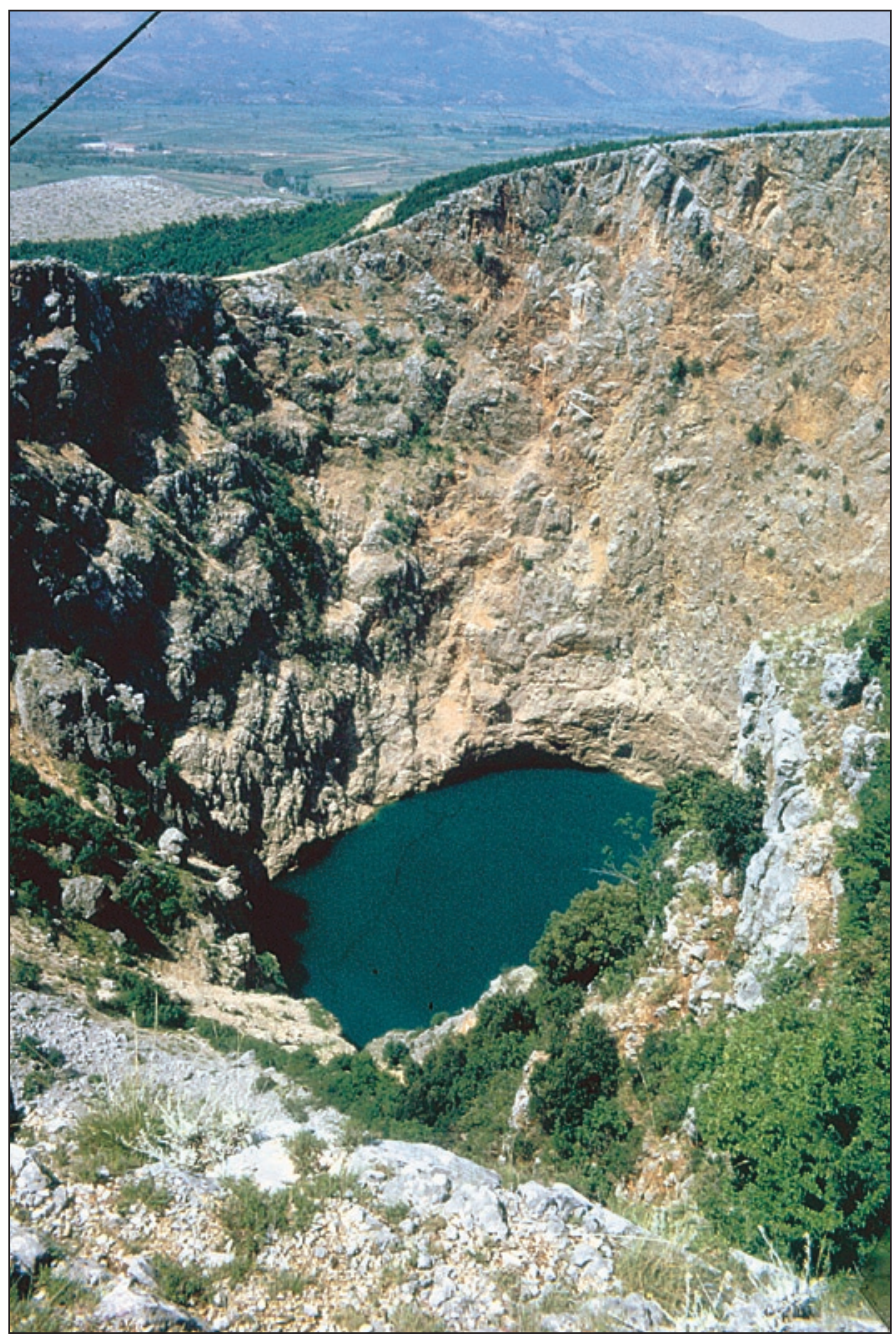

Photo 3: Red Lake in Hercegovina. (Photo I.Gams).

Foto 3: Rdeče jezero v Hercegovini. (Foto I.Gams). 
Pannonian hills in Slovenia. Poljes in Bosnia are drained partially to the Cetina and partially to the Vrbas. On the basis of the measurements of ex-federal Yugoslav hydrometeorological service we can calculate the amount of yearly dissolved carbonates in runoff. The chemical erosion in the drainage basin of the river Cetina is 51-60 and that of Vrbas 71-80 microns per year (Gams, 1982). Chemical erosion depends mostly from the run-off. Taking into account the precipitation at Livno (yearly $1155 \mathrm{~mm}$ ) the chemical erosion in limestone and dolomite from upper Miocene till now would be for the Cetina $612-720 \mathrm{~m}$ and for the Vrbas 852 - $960 \mathrm{~m}$. Solution in the loose carbonatic sediments is faster and this differences and the effect of erosion of sediments is seen in the height of polje rocky slopes. Thickness of Mesozoic limestone and dolomite in the Outer Dinarides is about 7000 m (Herak, 1972).

\section{TECTONIC POLJE WITHOUT TERTIARY SEDIMENTS}

The deepest and the smallest polje in the Slovenian part of the Inner Dinaric Karst is Globodol near the town Novo mesto. Its bottom at the altitude of $200 \mathrm{~m}$ is $4 \mathrm{~km}$ long and wide $1 \mathrm{~km}$. At eastern and western edge of the bottom are deep dolines. At higher level water rises in them through soil and later sinks through them. Two short caves on the eastern side $2-4 \mathrm{~m}$ above the bottom prove the ancient outflow, but on the surface of the basin at present the traces of running water are completely absent (Gams, 1959). In the middle of the bottom are loam and clay 1-2 m higher and there are three villages. The northern 2,5 km long part of the polje bottom is surrounded by $80-120$ $\mathrm{m}$ higher oval ridge of Jurassic (Kimmeridge) limestone, covered by Plio-Quarternary clay, loam

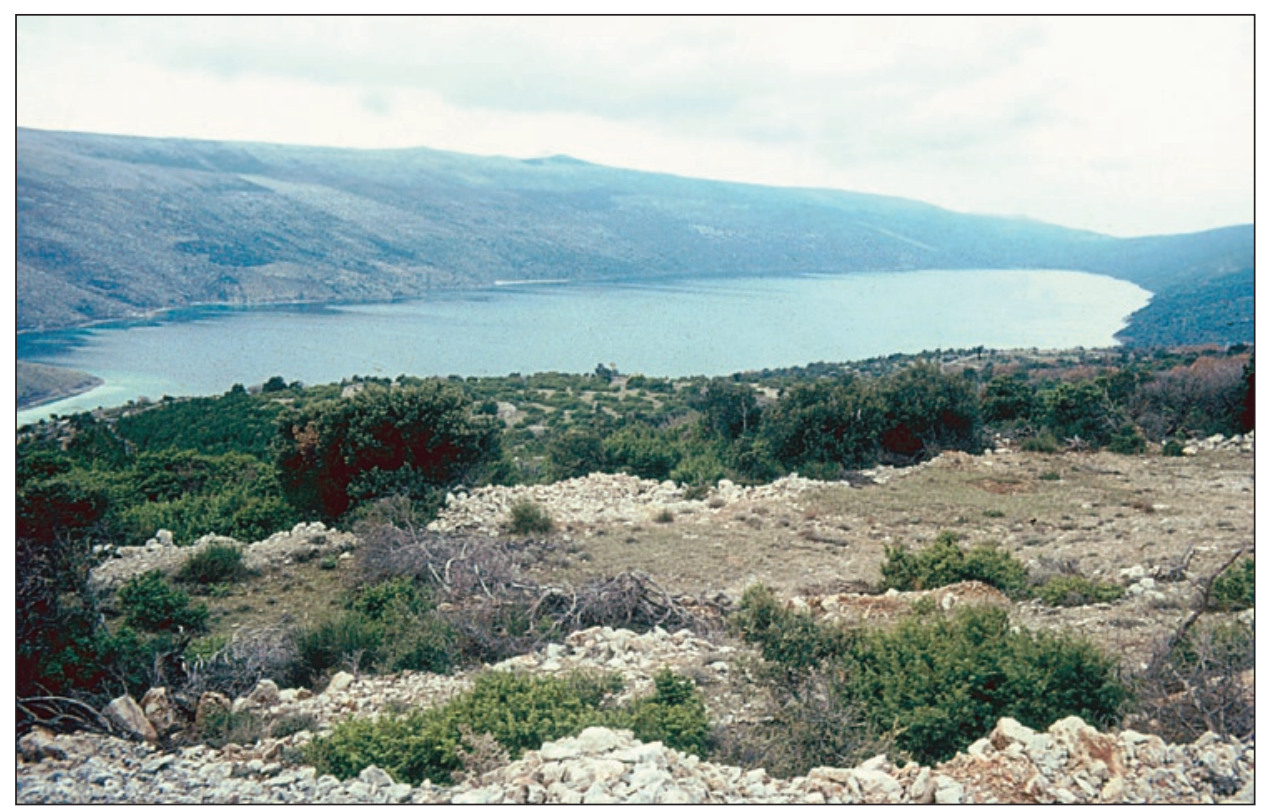

Photo 4: Lake Vrana on the island of Cres, taken from S. (Photo I.Gams).

Foto 4: Vransko jezero na Cresu od juga. (Foto I.Gams). 
and locally sand, connected with the larger equal belt in the basin of the village Mirna peč (acc. to geological map of Novo mesto of 1:100.000). In the southern corner of Globodol polje the bottom is covered by rendzina. Behind it rises the Ajdovec plateau $(593-300 \mathrm{~m})$, inclined toward $\mathrm{N}$, a result of the tectonics. Absence of fossils in the Plio-quaternary sediments prevents the geologists to make a more detailed classified age of these sediments and the geomorphologists to precise the period of polje development. It is obvious that the polje began to sink after the accumulation of Plio-Quaternary sediments.

On our photo (No 3) a hill Mali vrh (324 m) is visible inside of the polje. It is built of older (Oxford-Kimmeridge Jurassic) limestone than the rest of the polje ridge. It is not a proper hum as it is on the NW side by a lower prolongation connected with the polje slope. More or less round depression with flat bottom and a hill in the middle called ring has been found in many cases in the Dinarides in Slovenia and in formerYugoslavia (Gams, 1981, 1998). This forms are called ring structure. They are in the seismic areas presumably the newest tectonic elevations.

The piezometric level of the high inundation water in the polje Globodol is controlled by $5 \mathrm{~km}$ distant spring of the river Prečna, a tributary of the river Krka at the NE side of the Prečna basin. This is a part of the larger basin of Krka. Prečna basin is filled with lake and river sediments in form of clay, loam, silt and sand. The analysis of the fossils proved two accumulation phases, the first one in lower and the second in younger Quaternary (Šercelj, 1961). In this periods the tectonic sinking of the Globodol polje was presumably accelerated. $3 \mathrm{~km}$ eastward of Globodol is the depression with the spring of the river Temenica. Its bottom is $40 \mathrm{~m}$ higher than that of Globodol. Therefore it can not develop as a ancient valley of Temenica. With the long axes in the N-S is Globodol an exception in the Slovenian part of the Dinaric Karst. Without neotectonic sinking is nearly impossible to explain the development of the basin Globodol

River Unica rises from the Cave of Planina at SE corner of Polje of Planina built of Cretaceous limestone. At low water level it crosses the $2 \mathrm{~km}$ wide plain, built mostly of Triassic dolomite, to the sinks in Cretaceous limestone on the opposite side. With increasing water level is increasing also the length of river and when flooding the polje its end ponors are in the NE corner. The $6 \mathrm{~km}$ long Polje of Planina is known in the literature as an overflow polje. This notion supposes the accelerated solution during the water flow. But the hydrochemical measurements did not prove this (Zupan, 1974; Gams, 1981)

The $200 \mathrm{~km}$ long Idrija fault in direction NW-SE crosses the polje. Along it is $25 \mathrm{~km}$ distant town Idrija, the epicentre of the strongest earthquake in Slovenia (intensity X of EU). In the year 1511 it hit the large land. In the mercury mine Idrija in the period of 60 years has been established a dislocation of $1 \mathrm{~cm} / \mathrm{a}$. On the NW side of the fault the tectonics torn 3 lithological belts and dislocated them for $4 \mathrm{~km}$ to NE. After deepening the new valley for $240 \mathrm{~m}$ along $18 \mathrm{~km}$ the ancient $300-400 \mathrm{~m}$ deep old valley of Čepovan remained dry (Gams, 1998, $37-409)$. The Idrija fault is divided in several parallel faults (Placer, 1982). Čar and Gospodarič (1983) analysing Idrija fault between Planina and Cerknica poljes stated small displacements in the youngest tectonic phase which altered the effects of older ones. Čar (1978) discerned in the Planina polje faint fault, covered fault and strong fault in the direction SE-NW and transverse faults. Vrabec ( 1994) stated for the polje of Planina parallel faults without releasing bends on echelon arrangement of fault segments. Its romboidal shape is according to him oriented opposite to the geometry necessary to produce divergence in the right-lateral slip environment. The Planina depression could therefore be an initial stage of 
pull-apart basin. The Triassic dolomite along the Idrija fault(s) is in Planina polje in many place crumbled, faults blurred and uncertain. This is especially true in dolomite SE of Planina polje. Only the SE border of the Planina polje is not in straight line. There and in the polje have been drown by geologists different fault lines.

The development of the polje of Planina is here primary based on the geomorphological features. The greatest SE part of the polje is in form of a rectangle, $6 \mathrm{~km}$ long and $1.7 \mathrm{~km}$ wide. Outside of it are on SW corner the 0,6 km wide "bay" at Planina, NW triangle at Grčarevec, and the "bay" Babji dol.

The altitude of the polje bottom is between $446 \mathrm{~m}$ at Planina and $442 \mathrm{~m}$ in Babni dol. Between Planina and Babni dol (in straight line of $4 \mathrm{~km}$ ) the river bed of Unica makes more than 20 meanders, and some other are artificially cut . They indicate the idea of recent sinking bottom..

The polje bottom is around $70 \mathrm{~m}$ deeper than the surface in the lowland on NE and NW side of basin. With exception of the ridge of Jakovica and the SE side the bottom is confined by a $30-55 \mathrm{~m}$ high steep scarp in dolomite and on NE side in limestone. This scarps are parallel on both sides and till Laze in straight line even in the domain of dense sinks in limestone. It is a common phenomena that the old ponors in Dinarides end in deep "blind valleys". They are absent in our polje. Only in Babni dol (Škofji lom and Pod stenami) the northeast slope is locally displaced toward North. Without scarp is the hill Jakovica built of Triassic dolomite and at the northern foothill of limestone.

On NE side of the polje is the $4 \mathrm{~km}$ wide geological structural block of Vrhnika - Cerknica. Its is composed of 6 strips in the direction NNW-SSE. The age of the belts is diminishing toward West
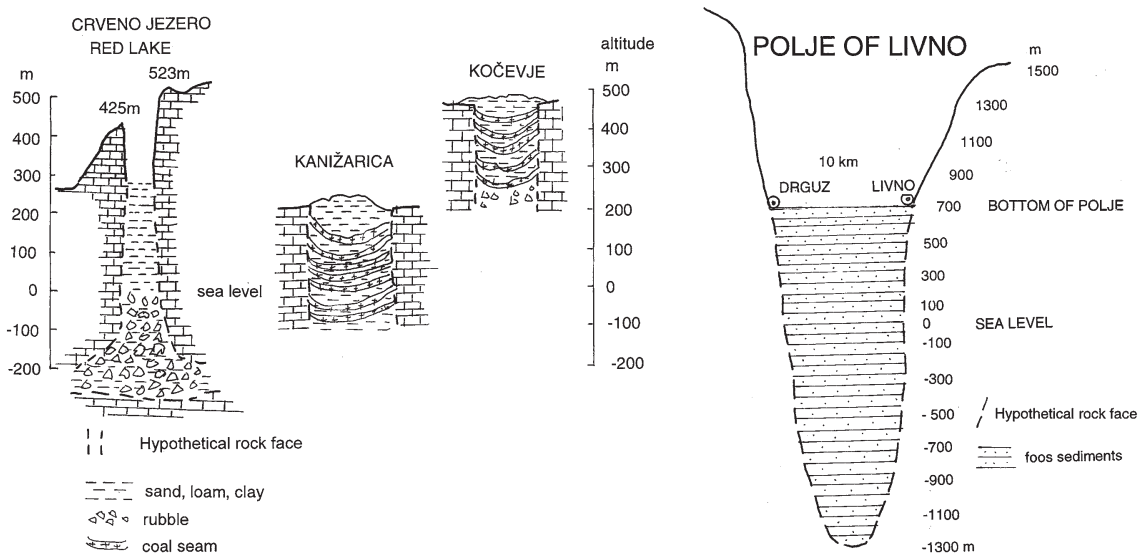

Fig. 3: Profiles of the polje of Livno, Red Lake, coal basins of Črnomelj and of Kočevje.

Sl. 3: Profili Livanjskega polja, Rdečega jezera in premogovnih kotanj Kanižarice ter Kočevja. 
from lower Jurrasic limestone to upper Jurassic one. At the NW part is a wider Cretaceous limestone with two patches of Eocene flysch. The same belts are on the western side of the Idrija fault in the mountain of Hrušica (see sketch ). There are in form of an arch as a consequence of shifting the Hrušica toward SE. The tectonic break in two pieces and tectonic shifting of the Cerknica - Vrhnika block along the Idrija fault towards SE for $10-25 \mathrm{~km}$ occurred after the Eocene.

The push apart of the limestone cap rock on the Triassic dolomite begins in the NW top of polje "triangle" at the Grčarevec and is increasing in with toward Laze on 1,7 -2,2 km. After this dislocation the polje development can begin.

The oldest altitude of the polje bottom can be reconstructed by the upper horizontal cave channels (vertical potholes at the entrances are not taken in account as they are collapse features). They are in the altitude $445-460$ (Gams, 1963). This is the altitude of the low hills at Laze which connect the Jakovica hill $(506 \mathrm{~m})$ with the eastern slope. In this caves and in Najdena jama the highest water level in the lowest part of caves is more than $10 \mathrm{~m}$ deeper than the bottom in the Babni dol. In one of the two artificially dug ponors (Putickove štirne) close to the rocky slope the water level falls below $425 \mathrm{~m}$, presumably along the fault voids. The "bay" form indicates the development by pull-apart tectonic

Jakovica hill $(506 \mathrm{~m})$ is presumably still rising. Its position in the polje bottom is similar to Mali vrh in the polje Globodol. The river Unica makes in distance of 1,5 km around Jakovica a great bend and nearly encircles the hill. At high water level it flows namely through the $1 \mathrm{~km}$ wide narrow between Jakovica and western Ivanji vrh in the Babni dol. There and behind the river bed SE of Laze is in limestone the same scarp in straight dinaric direction (NW-SE) parallel to scarp SE of Grčarevec below the Mt Planinska gora (1079 m, a part of the Hrušica Mt.).

The sediments of the polje bottom were after the second world war intensively researched for the proposed water accumulation for hydroelectric station at Vrhnika. Alluvial loamy accumulation is in average $4 \mathrm{~m}$ deep. Only near village Planina the loam contains small gravels. Pollen analyses have stated the Holocene age. In nearly one quarter of the bottom below loam are filled dolines, deep up to $25 \mathrm{~m}$, many also in the dolomite, especially near to limestone. Loam is a sediment of the perennial lake which recently take the whole polje bottom for 1-2 months in the year, in winter mostly, sometimes also in the other seasons sporadically (Gams, 1980).

In the Pleistocene cold phases this high part of Dinaric Slovenia was a cold steppe with grass and rare trees, so denudation on the slope enables the accumulation of weathered material in the poljes too. On the slope above polje in the Planinska gora (Planina Mountain,789 m) are in dolomite some ravines and below them spread rubble. But Planina polje was before the Holocene loamy accumulation a rocky plain with some sinks in the dolines. The rubble washed to polje may be dissolved by more aggressive water especially that a longer time frozen part in flysch in the Pivka drainage basin around Postojna.. But river transport of rubble in the polje bottom is possible only at higher flow speed as it is at present. This is a new argument for the tectonic origin of the polje bottom as it is at present.

The peasants of the villages have used in the middle and new age the polje bottom for pasture. For this type they used special name (in Slovenian log). On the less inundated higher parts of the bottom they have fields, too. To shorten the lake phases they under the overlord control reclaimed the river beds and ponors to accelerate outflow. This is better documented for the 19. and 20 century. Nevertheless on the grass after long lakes is still observed the accumulation of fine suspension as a 
continuation of the Holocene accumulation The granulation of the recent deposit of the flood water is: coarse sand $5 \%$, tiny sand $45 \%$, clay $30 \%$, silt $20 \%$.

The solution below the soil cover is active in the Babni dol, where the lake is the deepest and changes of accumulation into soil erosion and inversely along the dispersed flows are observed.

All this facts are in favour of the recently still active tectonic sinking of the bottom.

Reassuming this facts we can conclude that the SE rectangular part of the polje is mostly a tectonic sink and in Babni dol also an effect of border subsoil corrosion combined with the solution of mixing waters of Unec and once more active Hotenka.

\section{NEW GENERATION OF (LAKE) POLJES IN THE SINKING ADRIATIC PLAIN COAST}

The recent (Holocene) sinking of the lowland on the Adriatic coast and of the near islands have recently confirmed numerous findings of submerged Roman archaeological artefacts on the coast and in caves (Nicod, 2003), proved also by maritime station at Bakar (Šegota, 1982). It is evident in the microforms in the limestone coast in western Istrian Peninsula, in Ravni kotari and in some islands along the NE coast of Adriatic Sea. In Zagora (northern Dalmacija) at the mouth area of the river Zrmanja are two lakes. The Novigradsko more ("Sea of Novi grad ") is 5,5 km long and 2,4 $\mathrm{km}$ wide oval lake with outlet through the short gorge Novsko ždrilo. This is $22 \mathrm{~m}$ deep, but the lake is deeper, $-29 \mathrm{~m}$. This difference can be explained by recent sinking of coastal lowland (the same effect can come from the rising sea level). Mouth of the Zrmanja in the Novigradsko more is $3 \mathrm{~km}$ eastward of the gorge, the recent accumulation of river transport is evident. $2 \mathrm{~km}$ wide Karinsko more is connected with Novigradsko more by a river but it is without tributary; the accumulation of fluvial sediment is therefore modest, the basin smaller.

$30 \mathrm{~km}$ SE of Karinsko more is on the coastal plain the $13 \mathrm{~km}$ long, 2,2 km wide and 3,9 m deep Vrana lake. In NW part the bottom of the lake basin is covered by river alluvial transport from near flysch belt and by marshy sediments as accumulation of two small tributaries. Primary outflow of lake was only through ponors to the $1-2 \mathrm{~km}$ distant shore of Adriatic Sea, but in 1897 a channel for outflow was constructed and, recently abandoned. The Vrana lake is a part of a larger depression built on the NW side of fluvial sediments deposited by a long tributary. The same origin is also the $6 \mathrm{~km}$ long and at the beginning $7-25 \mathrm{~m}$ deep Proklansko jezero on the confluents of Krka and Guduća rivers.

According to Nicod (2003) the lakes in lowland of Ravni Kotari have been in Holocene filled with water during the Holocene sea level rising. The same geomophological effect has the tectonical sinking of coast. The formation of some kilometres long flat bottoms in the shallow basins by means of solution below the accumulated sediments with humus in the wet environment needs longer time than 10.000 years (lengths of the Holocene).

On the islands of Dalmatia some lakes have nearly the same level as the Sea (f. ex. on Mljet $46 \mathrm{~m}$ deep Great lake (Veliko jezero) and $26 \mathrm{~m}$ deep Little lake, both with saline water as their conduits in karst are in contact with sea water. This cryptobasins developed presumably in one of the cold phases of Pleistocene with lower sea water level and brackish water is aggressive all over the world.

The most known lake on the island Cres is Vrana lake in the Kvarner Bay. Its basin in Mesozoic limestone and dolomite, crossing by a narrow flysch belt, is $2 \mathrm{~km}$ wide and $6 \mathrm{~km}$ long. Its water 
level is above the sea level in the $7 \mathrm{~km}$ distant Kvarner Bay and oscillates very little during the year. The underground conduit has to be in form of a rising tube with upper curve near to the lake level and turned down in the second part. The genesis of lake basin can be explained with tectonically rising of the isles.

The shallow lakes listed near the town Zadar show the initial levelling of the polje bottom by means of biocorrosion and the extension of the basin with lateral solution.

\section{EXTREMELY DEEP DOLINES AND SMALL BASINS}

Close to the northern slope of the tectonic polje of Imotski is the famous collapsed doline Crveno jezero. Departing from the highest edge of pothole at $523 \mathrm{~m}$ the depth to the highest water oscillating level is $243-249 \mathrm{~m}$, it is nearly in the level of the near polje bottom of Imotski. The water level at the bottom of the collapse doline is $4 \mathrm{~m}$ above the sea level of the $26 \mathrm{~km}$ distant Adriatic Sea. The diameter of the collapse doline (recent $400 \mathrm{~m}$ ) is steady enlarging especial during the earthquakes. The near Imotsko seismic station registered in the period 1946 - 1989 the strongest earthquake of 7 degree of MCS. The earthquake of 1942 has considerably reduced the depth of the near Modro jezero (deep $190 \mathrm{~m}$ ) and triggered a great rockfall in Crveno jezero (Roglić, 1904, 179). If one earthquake of $7^{\circ} \mathrm{MCS}$ would occur in 36 years and the same frequence is supposed in the whole Holocene, we recognize strong effect of earthquakes on the widening of the Red lake and in all similar deep collapse dolines. Having in mind this fact we have to suppose below the doline bottom of Red Lake (now at $4 \mathrm{~m}$ above s.l.) a huge void and in them great accumulation of rocks The question arises which processes hollowed this void. Theoretically there are four possibilities:1. solution of mixing of sea and underground karst waters, 2. tectonics (pull - apart basin ), 3. genesis in the time of 100 $\mathrm{m}$ deeper Adriatic sea level in Pleistocene cold phases, 4. collapsing of the non firm carbonatic cover as caprock above the thick salt layers solved by underground waters (f.e. North-eastern Germany). We have no hint for the cases 1 and 4 in the Dinarides .

By strong seismic activity different depressions can develop. The $150 \mathrm{~m}$ deep doline Norin at polje of Nikšić is filled with limestone rubble, gravel and loam (Milanović, 1979, 44). In the $300 \mathrm{~km}$ long seismic mountainous and hilly area behind the Adriatic Sea between Split and Albanian border is a belt with $6-9^{\circ}$ of MCS earthquakes (in the years $1946-1982$ ). There are 17 poljes and uvalas with Paleogene (Eocene flysch), Neogene and Quaternary sediments, between them also Skadar Lake with its cryptodepression in form of deep dolines . The same origin are Lakes of Ohrid and Prespa.

\section{SMALL DEEP BASINS FILLED WITH PLIO- QUATERNARY SEDIMENTS}

\section{Cases of Kanižarica and Kočevje}

Bela Krajina is a12 km wide and in the direction N-S $16 \mathrm{~km}$ long low karst plain in the altitude of $180-220 \mathrm{~m}$ at the western part of the lowland of the Karlovac basin. In some places are rests of the once larger cover of Plioquaternary sediments. On the western side of plain is a sharp transition to high karst. South of the town Črnomelj is a rest of the Pliocene sedimentary cover on the Lower Cretaceous limestone and dolomite. The cover in size $2 \times 1.8 \mathrm{~km}$ consists of the Pliocene (Pontic) 
marls, sands and clays with coal. The coal seams (lignite) in this sediments have been exploited in the $19^{\text {th }}$ and $20^{\text {th }}$ century. 114 coal seams dip from all sides funnel-like down to the centre of the rocky basin as a prove of the contemporary sinking of the limestone bottom together with cap of sediments. Invasion of water from limestone wall have often interrupted the mining. The thickness of the coal bearing sediments is $300 \mathrm{~m}$ ( Bukovac et al., 1983). It means, the bottom of the basin is $100 \mathrm{~m}$ below the sea level. (The altitude of the Kanižarica is $199 \mathrm{~m}$ ). It is a cryptodepression in limestone.

The coal bearing sediments are on the surface separated from the Plioquaternary sediments on South by the straight tectonic line. $3 \mathrm{~km}$ distant to the west is the scarp of the high Dinaric karst with surface in altitude of $500-900 \mathrm{~m}$. Kanižarica basin is crossed by two long tectonic faults with continuation to the high karst at NW. The development of the small 300 m deep basin of Kanižarica is a result of the tectonic sinking in form of pull-appart basin between two fault lines both sides of the Pliocene coal bearing sediments

$40 \mathrm{~km}$ NW of Kanižarica is at the town Kočevje a similar basin filled with coal bearing. Upper Miocene and Plioternary sediments in the SE part of the $35 \mathrm{~km}$ long polje of Ribnica-Kočevje. They are built of limestone conglomerate, sandstones, marl and clay and in them are 6 seams of coal 0,7 - $22 \mathrm{~m}$ thick. In the lower basin, inclined to south, the grains are thicker, somewhere with thick stones, presumable of upper Miocene age. In the cap sediments are predominant the marl, clay and partially slates (Savić et al. 1983). The total depth of the filled basin is more than $200 \mathrm{~m}$. As at Kanižarica also here existed in $19^{\text {th }}$ and $20^{\text {th }}$ century a coalmine. After its end in the middle of last century the surface depression invaded the 650 x $900 \mathrm{~m}$ large lake. The coal basin is on the watershed of the rivers Krka and Kolpa, both are tributary of the Sava river.

Chemical erosion of carbonates in river basins of Krka and Kolpa, calculated from run-off and dissolved carbonates is $60-70$ and $80-90$ microns per year. The Plioquaternary sediments at Kanižarica and Kočevje contain less carbonates (Gams, 1981) and chemical erosion is modest. This is why the sediments before coal mining formed an elevation. The outflow from Kočevje sediments has hollowed out at higher level three horizons of caves in the hum Kofel (Kranjc, 1973).

\section{REFERENCES}

Baučić, I., 1967: Cetina. Razvoj reliefa i cirkulacije vode u kršu. Rad Geografskog instituta sveučilišta sveučilišta v Zagrebu, 6 sv. 1 -161, Zagreb. .

Bukovac, J., M.Poljak, M. Šušnjar, M. Čakalo, 1984: Tumać za list Črnomelj. Beograd.

Buser, S., 1974: Tolmač lista Ribnica. Geološki zavod Ljubljana. 1 - 60, Beograd.

Cvijić,J.,1895: Karst. Geografska monografija. Beograd.

Cvijić, J., 1900: Karstphänomen. Versuch einer morphologischen Monographie II. Teil. Die Karstpoljen. Abhandlungen der Geogr. Gesellschaft. Wien

Cvijić, J., 1960: La géographie des terrains calcaires.Monographies.T. CCC 12. Cl. Sciences Mathématiques et Naturelles. Ac. des sience et des arts, No 26, Beograd.

Čar, J., Gospodarič, R.,1983: O geologiji krasa med Postojno, Planino in Cerknico (About the geology of karst among Postojna, Planina and Cerknica). Acta carsologica, 12, 93 -106, Ljubljana.

Čar, J., 1987: Planinsko polje and Planina - Geology. In: Man's Impact in Dinaric Karst (Ed. I.Gams in P. Habič). 42 - 46, Ljubljana. 
Deeleman, C, Revision of the Cave dwelling in related spiders of the genus Troglohyantes Joseph (Lynichidae). Diss. Cl, IV, SAZU, Ljubljana.

Gams, I., 1959: H geomorfologiji kraškega polja Globodola in okolice (Contribution to the geomorphology of the karstic polje of Globodol (and its surrounding) in Slovenia). Poročila- Acta carsologica. 2, 27-66, Ljubljana.

Gams I., 1963: Logarček (Logarček Cave). Poročila (Acta carsologica) 3, 5 -74. Ljubljana.

Gams, I., 1968: Neka merenja intenziteta korozije u Dinarskom krasu i njihov značaj za geomorfogiju. Cvijičev Zbornik u spomen 100. godišnjice njegovog rodjenja, 83 - 93, Beograd.

Gams, I., 1973: Slovenska kraška terminologija (Slovene karst terminology). Ljubljana, 1- 67.

Gams, I., 1973: The terminology of the Types of Poljes. Slovenska kraška terminologija. 60 - 73. Ljubljana.

Gams, I., 1978: The polje: The problem of definition. Z.f. Geomorphologie, NH.22, 170 - 181.

Gams, I., 1979: On the mass movements triggered by earthquake in 1979 and neotectonics in Montenegro (S. Yugoslavia. Proceedings of the 15th Meeting »Geomorphological survey\&mapping (Modena), 1979, 117 - 127

Gams, I., 1980: Poplave na Planinskem polju (Inundations in the polje of Planina). Geografski obzornik XX, 1980, Ljubljana 1981. 7 - 34.

Gams, I., 1981: Morfografski sistemi u Jugoslaviji. Glasnik Srpskog geografsko društva 61,1, 7-19. Beograd.

Gams, I.,1981b: Chemical erosion of carbonates in Yugoslavia. Geographica Yugoslavica, 41-51. Bull. Union of the Geographical Societies of Yugoslavia, III. Ljubljana 1982.

Gams,I., Bognar, A., Lazarević, R., 1997: Former Yugoslavia. In: C.Embleton-Hamann: Geomorphological Hazards of Europe. 487 - 499.

Gams, I:, 1998: Relief. In: I.Gams-I.Vrišer (edit.), Geografija Slovenije. 24 -55, Ljubljana.

Gavrilović, D., 1974: Srpska kraška terminologija. Kraška terminologija jugoslovanskih naroda., II, 1-73. Beograd.

Grund, A., 1903: Die Karsthydrographie - Studien aus Westbosnien. Geographische Abhandlungen (Penck). 7/3, 1 -200, Wien.

Herak, M.,1972: Karst of Yugoslavia ( 25-84). In: Herak,M., T. Springfield: Karst - Important karst regions of the Northern Hemisphere, 1 - 552.

Jelavić, A., 1982: Priroda krša i krških polja. 1-186. Split.

Jennings, J., N, 1985: Karst Geomorphology. 1 - 293. Oxford.

Katzer, F., 1903: Geologischer Führer durch Bosnien and Herzegovina. IX. Int. Geologenkogress, Sarajevo.

Katzer, F., 1909: Karst und Karsthydrographie. Zur Kunde der Balkanhalbinsel. Reisen und Beobachtungen. Erkunde, 9. Sarajevo.

Kranjc, A., 1974: Primer razvoja huma na Kočevskem polju. Naše jame 15 (1973), 65-70, Ljubljana.

Kranjc, A., F. Lovrenčak, 1981: Poplavni svet na Kočevskem polju (Floods in Kočevsko polje). Geografski zbornik 21, 1-39.

Lehmann, H., 1959: Studien über Poljen in den venezianischen Voralpen und Hochapenin. Erdkunde. B. 13, $248-289$, Bonn.

Nicod, J., 2003: Les karsts dinariques - paysages et problèmes. Slovénie, Croatie, Bosnie-Herzégovine, Monténégro. Karstologia. Mémoire No 10 - 2003. Marseille 
Mojsisowics, E., 1880: Westbosnien und Türkisch-Croatien. Jahrbuch Geolog. R.A., Wien.

Mijatović, B., 1984: Karst poljes in Dinarides. Hydrology of the Dinaric karst. International contributions to hydrology, 4, $87-109$. Hannover.

Placer, L., 1982: Tektonski razvoj idrijskega rudišča (Structural history of the Idrija mercury deposit), Geologija, 7 - 94.

Petermanns Geogr. Mitteilungen,VI, P. 121-127, VII, 156-162 and VII, p. 177-181, Gotha 1909.

Rathjens, C. 1960: Beobachtungen an hochgelegenden Poljen in südlichen Dinarischen Karst (Ein Beitrag zur Frage zur Enstehung und Datierung der Poljen. 141 -151, Z. Geomorphologie, 4.2.

Roglić, J.,1940: Geomorphologische Studie über Duvanjsko Polje (Polje von Duvno) in Bosnien. Mitteilungen von Geographischen Gesellschaft in Wien

Roglić, J., 1954: Polja zapadne Bosne i Hercegovine. Zbornik s Trećeg kongresa geografa Jugoslavije (1953). Sarajevo 1954 (Translation: Poljes of Western Bosnien and Hercegovina).

Roglić, J., 1974: Prilog hrvatskoj krškoj terminologiji. (Contribution to Croatian karst terminology). In:Karst terminology of peoples of Yugoslavia, 1-72. Zagreb.

Roglić, J., 2004: Odnos riječne erozije i krškog procesa. Krš i njegovo značenje.(collection of Roglić collected publications). Geografsko društvo Split et al., Split-Zadar- Zagreb, 360 p.

Milanović, P., 1979: Hidrogeologija karsta i metode istraživanja. 1-305.Trebinje.

Savić, D., Dozet S., 1985: Tumač za list Delnice (L. 33 -90). Osnovna geološka karta SFRJ 1 : 100.000, Beograd

Šegota, T., 1982: Razina mora i vertikalno gibanje dna Jadranskog mora od ris-wirmskog interglaciala do danas. Geološki vjesnik 35, 93- 109. Zagreb.

Šercelj, A., 1961: Staropleistocenska vegetacija v Zalogu pri Novem mestu. Razprave SAZU, IV.r., št. 6, s.363- 417, Ljubljana.

Vrabec, M., 1994: Some thoughts on the pull-apart origin of karst poljes along the Idrija strike-slip fault zone in Slovenia, Acta carsologica, 23, 155 - 168, Ljubljana.

Sweeting, M. . 1972: Karst landforms. Macmillan, 362 p., London.

Zupan, M., 1974: Poročilo o fizikalno-kemijskih analizah vode (3. del.) Report nr. 3, SUWT, Ljubljana. 